\title{
Az Eszterházy-uradalom gazdálkodása a 18. században (Pápa-Ugod-Devecser)
}

Gróf Eszterházy ${ }^{1}$ Károly püspök családi birtoka, a pápa-ugod-devecseri uradalom 18. századi, az úrbérrendezés korszakát is magába foglaló megszervezésének és gazdálkodásának történetét a rendkívül hiányos forráslehetőségek keretei között a Pápa város históriáját bemutató tanulmánykötetben foglaltuk össze. ${ }^{2}$ A domíniumra vonatkozó, fennmaradt gazdasági feljegyzések további elemzését - a dolgozatban terjedelmi korlátok miatt nem közölt, illetve a folytatódó kutatások nyomán azóta napvilágra került adatok közlésével - mindenképp indokolta a korszak agrártörténeti jelentősége, a nagybirtok úrbérrendezés előtti és azt követő időszakban folytatott mezőgazdálkodásának vizsgálata. E vizsgálódásaink eredményeit a KomáromEsztergom Megyei Múzeumok Közleményeiben 2012-ben megjelent tanulmányban tettük közzé. ${ }^{3}$

A pápai uradalom az 1762. évi családi birtokosztályt követően került egyedüli birtokosként - testvérének, Esterházy Ferenc (1715-1785) kancellárnak ${ }^{4}$ fizetendő bizonyos járadék kötelezettségével - Károly püspök kezére. Itteni önálló gazdálkodása kezdetén a domínium irányítását Balogh Ferenc (1708-1765)

1 A családnév írásában a szakirodalmi gyakorlatnak megfelelően, Eszterházy Károly saját kezű aláirásaiban tükröződő névhasználati gyakorlatát követjük.

2 Fülöp Éva Mária: A pápa-ugod-devecseri Esterházy-uradalom megszervezése és gazdálkodása a 18. század folyamán. In: Tanulmányok Pápa város történetéből (A kezdetektől 1970-ig). Főszerk. Kubinyi András. Pápa 1994. 225-284.

3 Fülöp Éva Mária: A pápa-ugod-devecseri Esterházy-uradalom gazdálkodása a 18. században, különös tekintettel az úrbéri rendezésre I. Komárom-Esztergom Megyei Múzeumok Közleményei 18. Tata 2012. 129-155.

4 Gróf Esterházy Ferenc kancellár, a tatai uradalmat megvásárló Esterházy József gróf (1682-1748) országbíró unokaöccse, az 1762. évi tatai családi tanácskozáson tett birtokosztályig testvérével, Eszterházy Károllyal közösen bírta a pápai és ugodi birtokokat, de unokatestvérük, Esterházy József gróf (1714-1762) altábornagy tatai uradalmában is nagy befolyása volt a gazdálkodás irányításában. 
régensre, a nagy tekintélyű tatai jószágkormányzóra bízta. ${ }^{5}$ Balogh régens halálát követően a gazdálkodás a mindenkori pápai prefektus vezetésével folytatódott. ${ }^{6}$

Balogh Ferenc jól ismerte a pápai uradalmat, hiszen birtokgazdálkodási ügyekben rendszeres kapcsolatban állt Esterházy Ferenc kancellárral és annak édesapjával, gróf Esterházy Ferenc (1683-1754) tárnokmesterrel is. ${ }^{7}$ A magasabb rangú tisztviselők szolgálatait — hasonlóan például a tatai domínium gyakorlatához —, a pápai uradalomban is több esetben jutalmazták inscriptióval, házra, földre, esetleg részbirtokra kiterjedően. Az uradalom telekkönyvében, az inscriptionalisták közt megtalálhatjuk a pápai házzal honorált Balogh Ferenc nevét. ${ }^{8}$

A régens a pápai jószágkormányzat vezetőjeként, a tatai tapasztalatok alapján, sok esetben szorosan az ottani mintákat követve törekedett rendezni a gazdaságirányításban is kitűnő érzékủ püspök birtokait. 1764-től ebben a domíniumban is plenipotentiariusi megbízatással látta el feladatát. ${ }^{9}$

Balogh Ferenc régens uradalmi igazgatási tevékenysége az 1767. évi úrbérrendezés előtti időszakot fogta át, az 1740-es évektől kezdődően a tatai, gesztesi, semptei, illetve 1762-1765 között a pápa-ugod-devecseri uradalmak gazdálkodásában.

A pápa-ugod-devecseri uradalom 1735. évi felmérése alapján az évben az 1841 telekből 896 (48,66\%) volt megszállítva. ${ }^{10}$ Az uradalmi irányítás az 1760-as évek

5 Balogh Ferenc prefektus, plenipontentiarius, régens pályafutásáról lásd részletesebben: Fülöp Éva Mária - Schmidtmayer Csaba: Galántai Balogh Ferenc (1708-1765) régens. A billegpusztai rezidenciális központ. (Libelli Tatenses 3). Tata 2017.

6 Fülöp Éva Mária: A Pápa-Ugod-Devecser uradalom a XVIII. században és az 1829. évi családi egyezség. In: Emlékkönyv galántai és fraknói gróf Eszterházy Károly egri püspök, Pápa város földesura, mecénása és építtetője halálának kétszázadik évfordulója tiszteletére. Szerk. Hermann István - Mezei Zsolt. Pápa 2000. 63-75.

7 A családi birtokosztályok során Esterházy Ferenc semptei és pápai főkapitány (1641-1683) három fia 1702-ben, édesanyjuk halálát követően kötött először egyezséget öröklött javaikról. A legidősebb fiú, Esterházy Antal gróf (1676-1722) Gesztes várat és domíniumot, öccsei, József és Ferenc, a későbbi országbíró, illetve tárnokmester, a semptei és Pápa-Ugod-Devecser birtokokat kapták.

8 A házat 1748-tól bírta, s azt halála után örököseitől az uradalom 400 Ft-ért visszaváltotta. A „Balogh Ferenc nevezetű ház” piac felőli szobájában kalmárbolt működött, a konyhát és a másik szobát évi 40 Ft-ért bérbe adták. Magyar Nemzeti Levéltár Országos Levéltára (a továbbiakban: MNL OL) Az Esterházy család tatai levéltára (a továbbiakban: ETL) Domínium Tata. P 198 Fasc. 45. A tatai és gesztesi domíniumok számadáskönyvei 1746-1758. N. 12. , 16., 33-34.; MNL OL Az Esterházy család pápai levéltára (a továbbiakban: EPL) Domínium Pápa. P 1216 C. 51. N. 1. pp. 189-190. Tóth István pápai prefektus levele gr. Eszterházy Károlyhoz. Pápa, 1765. júl. 8.

9 MNL OL EPL Domínium Pápa. P 1216 A pápai uradalom lajstromozott iratai. C. 51. N. 1. Prothocolum Papense Correspondentiarum a dato 30e Octobris 1759 usque 26a aevembris 1766 inclusive. pp. 135-137. Balogh Ferenc levele gr. Eszterházy Károlyhoz. 1764. febr. 3.

101 egész telekhez 60 pozsonyi mérős szántóföld, 12 kaszás rét, valamint belsőség (házhely és kert) tartozott. Egy pozsonyi mérő vetésre 528, egy kaszás rétre 1584 ölet, a házra és kertre 14 öl széles, 71 öl 2 láb hosszú telket számítottak. Így egy egész telek (1000-1300 Döles holddal 
derekára épült ki teljes vertikumában: a birtokközpontban, Pápa mezővárosban működtek a központi irányító adminisztratív-gazdasági szervek (itt volt a prefektus, a tiszti ügyészek, a levéltáros, a számvevő székhelye). A Devecser oppidumhoz tartozó birtokrész gazdasági rendszere a pápainak volt alárendelve, az Ugod mezöváros nevével jelzett jószág gazdálkodása pedig nem különült el a központi birtoktesttől. ${ }^{11}$ Pápán és Devecserben tiszttartóságot építettek ki. A devecseri rész értékét az uradalom balatoni szőleihez közeli fekvése adta, a mezőgazdálkodás nagyobb mérvü kiterjesztésére csak a század utolsó harmadában került sor. Devecserben két út találkozott: a Pápáról és Veszprémből jövők, így ott a bormérés igen jól jövedelmezett, s nem véletlen, hogy 4-5 bolt is müködött a mezővárosban. ${ }^{12} \mathrm{~A}$ bakonyi erdők irányítását 1762-től - a pápai prefektus alárendeltségében működő - főerdész látta el Ugodon. ${ }^{13}$

Az uradalom possessiói határában a vízrendezési munkálatokra is nagy szükség volt. 1769-ben Tóth István pápai prefektus biztosította földesurát, hogy a vízelvezető és a malmok hajtására szolgáló, illetve a halastavakhoz készülő kanálist úgy tervezte, ahogy azt már Balogh Ferenc idejében elgondolták. ${ }^{14}$

Az 1720-30-as években az uradalom jövedelmei közt a gabona- és faeladások s - a domínium sajátos jellegéből következően - a bakonyi legelőbérletek, a sertéstenyésztés voltak a túlnyomóak, amelyekhez a boreladás haszna társult. ${ }^{15}$ Erre alapozva az „eröskezü kormányzô" ${ }^{16}$ Balogh régens az uradalomban újjászervezte az erdőgazdálkodást, ${ }^{17}$ hiszen tetemes hasznot remélt az ölfaeladásból. Úgy gondolta megoldani az értékesítést, hogy mivel Győrhöz a Bakony közelebb van, mint a vértesi erdők, ezért az lehet az eladás elsődleges célpontja, de Tata és Gesztes erdeiből Pozsonyba is szállíthat. Eszterházy Károly szerint: „Ottis lesz ittis haszon a fábúl...”. ${ }^{18}$ A faeladás,

számítva) mintegy 40-47 holdnak felelt meg. Fülöp É. M.: A pápa-ugod-devecseri Esterházyuradalom megszervezése i. m. 246-248.

11 Fülöp É. M.: A Pápa-Ugod-Devecser uradalom a XVIII. században és az 1829. évi családi egyezség i. m. 66.

12 Uo. 68.

13 Fülöp É. M.: A pápa-ugod-devecseri Esterházy-uradalom megszervezése i. m. 255.

14 Magyar Nemzeti Levéltár Veszprém Megyei Levéltára (a továbbiakban: MNL VEML) XI. 602/b. p. 330-334. Tóth István pápai prefektus levele gr. Eszterházy Károlyhoz. Pápa, 1769. jún. 8.

15 Fülöp É. M.: A pápa-ugod-devecseri Esterházy-uradalom megszervezése i. m. 238.

16 A majki kamalduli remeteség. 1733-1782. (Összeáll.) Weisz János lelkész. Várgesztes 1983 (kézirat), 10.

17 A fuvarpénz, az ölfavágás a jobbágyok „jobb előmenetelét”, s így az uradalom felé készpénzszolgáltatásaik könnyebb teljesítését is jelenthette a régens szerint. Fülöp É. M.: A pápa-ugoddevecseri Esterházy-uradalom megszervezése i. m. 255.

18 MNL OL EPL Domínium Pápa. P 1216 C. 51. N. 1. p. 62. Balogh Ferenc régens levele gr. Eszterházy Károlyhoz, a püspök rávezetésével. Csákvár, 1762. okt. 8. 
a tervezett bevételek miatt Balogh Ferenc a jobbágyokat és a „faragó embereket”, ${ }^{19}$ a bakonyi falvak kézműveseit kitiltotta az erdőkből. Rendelést tett mészégetésre és -eladásra, téglakemencék építésére. Meghagyta, hogy a kasszában mindig legyen félretéve legalább hatezer forint favágásra és borvásárlásra. ${ }^{20}$

A régens hamarosan már azt állapíthatta meg, hogy az ölfavágáshoz lassanként hozzászoktak a pápai uradalom subditusai. ${ }^{21} \mathrm{Az}$ új szolgáltatás megkövetelésének nyomatékosítását szolgálta a tamásiak esete. 1764-ben a falu Baloghtól a kocsmaárendát kérte, de mert fát még nem vágtak, és így „engedetlenek” ${ }^{22}$ voltak, azt nem kapták meg, sőt, mert contractusuk is letelt, a régens büntetésként ismét „robotra vette" őket. A rendelkezések következtében a bakonyi sertéstartás ${ }^{23}$ és fakitermelés haszna továbbra is a jelentősebb bevételek közt szerepelt.

Az erősödő allodizáció jeleként, 1765-ben 28 jármos ökröt hajtottak a pápai uradalomba Egerből, emiatt növelni kellett a béresek számát. ${ }^{24}$ Még ugyanabban az évben további 234 marhát hajtottak át Egerből, melyekből 14 tinó és a bikák a pápai, a többi állat a devecseri majorba kerültek..$^{25}$

Az uradalom gazdálkodását továbbra is a főként a hagyományos, fa-bor-gabona eladására épített, e bevételi forrásokat erősítő gazdasági rend jellemezte, de törekvésüket a piaci lehetőségek jobb kihasználására az allódiumok erősítése mellett a regálék visszaváltása is jelzi. Ismét saját kézbe vették a sör- és pálinkaházakat, a kocsmáltatást, amely egyre több bevételt hozott. ${ }^{26} \mathrm{~A}$ kocsmaházak ellátásra az allodiális

19 Fülöp É. M.: A pápa-ugod-devecseri Esterházy-uradalom megszervezése i. m. 255.

20 Uo. 256.

21 A pápai tiszttartó Baloghhoz intézett levele szerint Pápán, a várnál volt ekkor 1300 öl Koppány, Szentivány, Ság, Szűcs által vágott fa, ezt Győrbe szánták eladásra. Gyimót és Csót is a várhoz hordott fát, míg a nórápiak és kúpiak a serházhoz és a téglakemencéhez, ott 600 ölet tároltak. A tiszttartó Baloghnak írt levelében nem említette a munkába bekapcsolódott falvak közt Gannát, Bébet, Fenyőfót, Teszért. Nyárád sem vitt még semmit, de Nyögér már hordott fát, s készültek az ugodiak is. MNL OL EPL Domínium Pápa. P 1216 C. 51. N. 1. p. 128-129. Balogh Ferenc régens levele gr. Eszterházy Károlyhoz. 1764. jan. 10.

22 MNL OL EPL Domínium Pápa. P 1216 C. 51. N. 1. p. 128-129. Balogh Ferenc régens levele gr. Eszterházy Károlyhoz. 1764. jan. 10.

23 Eszterházy Károly Balogh levelére írt rávezetésében a makkot „édes Bakonyi gyümölcs”-nek nevezi. MNL OL EPL Domínium Pápa. P 1216 C. 51. N. 1. p. 58-60. Balogh Ferenc régens levele gr. Eszterházy Károlyhoz. Tata, 1762. szept. 10.

24 Fülöp É. M.: A pápa-ugod-devecseri Esterházy-uradalom megszervezése i. m. 258.

25 A hajtókat 4 db 2 éves üsző illette munkájukért. MNL OL EPL Domínium Pápa. P 1216 C. 51. N. 1. p. 205-206. Tóth István pápai prefektus levele gr. Eszterházy Károlyhoz. Pápa, 1765. dec. 9.

26 Fülöp É. M.: A pápa-ugod-devecseri Esterházy-uradalom megszervezése i. m. 256-257.; Hudi József: Esterházy Károly birtokigazgatása levelezése tükrében (1759-1799). In: Emlékkönyv galántai és fraknói gróf Eszterházy Károly egri püspök, Pápa város földesura, mecénása és építtetője halálának kétszázadik évfordulója tiszteletére. Szerk. Hermann István - Mezei Zsolt. Pápa 2000, 81. 
borok mennyisége nem volt elegendő, azt a hegyvámból, dézsmából, ${ }^{27}$ egyéb szolgáltatásokból befolyt borokkal ${ }^{28}$ kellett pótolni. ${ }^{29}$

Balogh javasolta a püspök-földesúrnak, hogy a bevételek harmadik nagy forrását jelentő, eladható gabona mennyiségének növelésére a kilencedet és a tizedet szemben kérjék a jobbágyoktól. ${ }^{30}$

A gazdálkodás valódi intenzív fordulatát jelentő belterjes, istállózó állattartásra történő átállást - annak vonzatával, a vetésforgókban művelt földekkel, a termesztett takarmányokkal - még nem sürgették a nagy, benépesítetlen területek, a rengeteg erdők, a gabona eladhatósága a vízi szállítás révén elérhető közelségű nagyvárosokban és katonai élelemtárakban. Így 1763-ban a nem sokkal azelőtt építeni kezdett pápai és devecseri „svájcerájokat” granáriummá alakították át. ${ }^{31}$

A kor érdekes átmenetet jelent a tapasztalatra alapozott (empirikus) és az elméleti megalapozottságú gazdálkodás között. A század végére hazánkban elkezdödő felsőfokú agrárszakoktatás, uradalmi szakemberképzés megelőző formájának, ugyanakkor alapvetően még az empirikus felkészülés alkalmazásának is felfogható a tatai uradalom különféle gazdasági hivatalaiban, Balogh Ferenc felügyelete alatt gyakorló, gazdasági pályára készülő fiatalok képzése.

A pápai magánföldesúri és egri javadalmas birtokok gazdálkodása számos ponton összefüggött, különösen, ha gazdasági újításokról volt szó. A termékek rendszeres közvetítésére, miként az előzőekben is bemutattuk, több példa akad a pápai és egri uradalmak között, de szoros kapcsolatot találhatunk a gazdasági tisztségviselők képzését illetően is.

27 Amint a pápai prefektus meg is fogalmazta, a „Dézsmabéli a Bor nem tartani való”, ezért ezeket a borokat árultatták. MNL OL EPL Domínium Pápa. P 1216 A pápai uradalom lajstromozott iratai. C. 51. N. 3. p. 219-220. Kiss Ferenc pápai prefektus levele gr. Eszterházy Károlyhoz. 1779. jan. 25.

28 A pápa-ugod-devecseri uradalomban 1761-ben az allodiális borok Badacsonyból és Kisörsröl jöttek be. a pincében a legrégibb allodiális bor 1756-os évjáratú volt. MNL OL EPL Domínium Pápa. P 1216 C. 51. N. 1. p. 26-27. Thanhoffer József pápai prefektus levele gr. Eszterházy Károlyhoz. Pápa, 1761. márc. 16. Hegyvám járt az uradalomnak Kisörs, Szentbékkálla, Ecséd, Szentivány, Szűcs, Kemenesalja szőlőhegyeiről.

29 1762-ben Balogh régens azt jelezte, hogy nem várható több termés 2000 akónál, ám az éves szükséglet az uradalomban 7-8000 akó. MNL OL EPL Domínium Pápa. P 1216 C. 51. N. 1. p. 62. Balogh Ferenc régens levele gr. Eszterházy Károlyhoz. Csákvár, 1762. okt. 8.

30 A tatai és gesztesi uradalmakban egy jobbágy minden elvetett mérő után fél-fél forintot, a kilenced és tized együttes összege helyett a mérőszámnak megfelelő fél pozsonyi mérő szemet szolgáltatott a szerződéshez kapcsolt egyéb munkákon kívül. Fülöp É. M.: A pápa-ugod-devecseri Esterházyuradalom megszervezése i. m. 256.

31 Uo. 257. 
A püspöki birtok tisztiszéke (oeconomi/clalis conferentialsessio), azaz „a számadó tisztek kollektív tanácskozása"32 1764. április 22-től minden hét pénteken, később negyedévente tartotta üléseit a püspöki székhely és birtokközpont Egerben, különösen, hogy „a dunántúli magánbirtoka igazgatását már megszervezett püspök tudatosan a gazdatisztek nevelő intézményének is szánta a gazdasági üléseket”. ${ }^{33}$ Eszterházy Károly emellett a Balogh Ferenc által felkészített gazdatisztekre is számított uradalma tisztikarában. Így amikor 1763-ban számtartóra volt szüksége a püspöki birtokon, ${ }^{34}$ azt kérte Baloghtól, hogy „tanítványai közül”35 javasoljon valakit. Ez kétséget kizáró megfogalmazása annak, hogy Balogh Ferenc irányítása mellett a tatai uradalom különféle gazdasági hivatalaiban megindult, létezett ez a képzési forma. Sajnos, összehasonlító kutatások e korra és erre az átmeneti képzési formára más nagybirtokok vonatkozásában célzottan még nem történtek, aminthogy arra sem, hogy az Esterházyak családi, illetve az egyházi méltóságot viselő családtag révén javadalmas birtokán kívül más nagybirtokokra is képzett-e Balogh Ferenc gazdasági tisztségviselőket.

A püspök fentebb említett kérésére Balogh Ferenc 1764-ben egy pápai számtartósági gyakornokot (practicánst) küldött Egerbe. ${ }^{36}$ Nagyobb jelentőségü a püspöki birtok irányítása szempontjából, hogy a tatai uradalom hivatalaiban tanult az egri Ulrich János, aki 1763 tavaszán - akkor még mint egri tiszttartó - érkezett Tatára, hogy Balogh Ferenc mellett fejlessze tudását. Amint Eszterházy Károly írta, jó lenne, ha egri jószágát is Balogh régens szedné rendbe, de mivel ez a nagy távolság és Balogh számtalan feladata miatt nem lehetséges, elküldi a tiszttartót, hogy a tatai uradalom gazdálkodását tanulmányozza. Elöírta, hogy a gazdálkodásban az ölfavágás, a téglaégetés, az irtások belső rendje, az épületek milyensége, a regálék hasznának megbecsülése stb. legyen tapasztalatszerzésének tárgya. ${ }^{37}$ A püspöki birtokon a prefektusságig emelkedett Ulrichot „Egerben és részben Tatán szisztematikusan

32 Bán Péter: Az egri püspöki uradalom igazgatása Eszterházy Károly idején. In: Eszterházy Károly Emlékkönyv. Szerk. Kovács Béla. Eger 1999. 273.

33 Uo. 278.

34 A pápai és egri uradalom egységes szemléletű kezelése bizonyítékaként a püspök úgy rendelkezett, ha a pápai uradalomból tennék át a számtartót Egerbe, akkor Pápára kell keresni helyette valakit.

35 MNL OL EPL Domínium Pápa. P 1216 A pápai uradalom lajstromozott iratai. C. 51. N. 1. Prothocolum Papense Correspondentiarum a dato ${ }^{30 \text { a }}$ Octobris 1759 usque $26^{\text {ae }}$ Novembris 1766 inclusive. pp. 124-126. Balogh Ferenc levele gr. Eszterházy Károlyhoz. 1763. dec. 7.

36 Az alkalmas személyt a régens a pápai uradalom egyik birkása fiában vélte megtalálni, aki már harmadik esztendeje volt gyakornok a pápai számtartónál, illetve a számvevőnél, s mindkettő dicsérte. MNL OL ETL P 197 Familiaria 1528-1903. Fasc. 107. N. 5. Balogh Ferenc levele gr. Eszterházy Károlyhoz. Tata, 1764. jan. 10.

37 MNL OL ETL P 197 Familiaria 1528-1903. Fasc. 107. N. 3. p. 113. Gr. Eszterházy Károly levele Balogh Ferenchez. Eger, 1763. febr. 7. 
oktatják az építkezések menetére" is. ${ }^{38} 1763$ júniusában Balogh beszámolót küldött Károly püspöknek, mely szerint Ulrichhal addig a tisztiszéki ülések (conferentia) jegyzőkönyveit olvastatta, s ezeket az egri tiszttartó nagyrészt le is másolta. A számadások (perceptorium) formálása, a számtartóság és kebelbeli számvevőség (gremiális exactoratus) müködése, a számtartó (exactor), az erdőmester (forstmeister), a tómester (halastavak mestere, „teicht meister") feladatainak megismerése is része volt a képzésének. Az uradalmi épületekről a tudnivalókat maga Balogh Ferenc magyarázta el neki. ${ }^{39}$ Összefoglalóan s Baloghnak elsősorban még a gyakorlati, személyes tapasztalatra alapozott megközelítésre épülő módszerére is rávilágító módon „valami tsak eszemben jutott mindeneket megmondottam néki, magammal minden felé elhordoztam, és valami Szemünkben tűnt megmagyaráztam”. ${ }^{40}$

Mindezért Károly püspök meleg hangú köszönetet mondott Baloghnak: „Köszönetet mondok kegyelmednek, minden fáradságáért, mellyel tanította Ulrichot.”¹1 1764-ben, nyilván Ulrich János hasznosnak bizonyult példája nyomán, taníttatásra kívánta küldeni Balogh Ferenc mellé az egri kasznárt, a kulcsárt és az összetett feladatkörü építési írnokot (Bauschreiber) is. ${ }^{42}$

Az 1760-as évek derekán az úrbéri rendezést megelőző időszak nyugtalansága érezhetővé vált a pápai uradalomban is. A várható központi szabályozást újabb szerződések megkötésével kívánták megelőzni, különös tekintettel az addig szokásjog alapján („,usus szerint”) ${ }^{43}$ szolgáltató falvakban. ${ }^{44} 1763$-ban, a püspök kérésére, Balogh régens minta gyanánt elküldte Egerbe a tatai uradalom szerződéstípusait: az örökös jobbágyok, az örökös jobbágyok mellé települt német és szlovák jobbágyokkal (advenák, hospesek) népesített falvak, a tisztán német ,jövevényekkel”45

38 Cs. Dobrovits Dorottya: Építkezés a 18. századi Magyarországon. (Az uradalmak építészete). (Mủvészettörténeti füzetek 15) Bp. 1983. 30.

39 MNL OL ETL P 197 Familiaria 1528-1903. Fasc. 107. N. 5. Balogh Ferenc levele gr. Eszterházy Károlyhoz. Tata, 1763. jún. 1.; Cs. Dobrovits D.: Építkezés i. m. 30.

40 MNL OL EPL Domínium Pápa. P 1216 A pápai uradalom lajstromozott iratai. C. 51. N. 1. Prothocolum Papense Correspondentiarum a dato 30 Octobris 1759 usque 26 $6^{\text {ae }}$ Novembris 1766 inclusive. pp. 107-108. Balogh Ferenc levele gr. Eszterházy Károlyhoz. 1763. máj. 12.

41 MNL OL EPL Domínium Pápa. P 1216 A pápai uradalom lajstromozott iratai. C. 51. N. 1. Prothocolum Papense Correspondentiarum a dato 30 Octobris 1759 usque $26^{\text {ae }}$ Novembris 1766 inclusive. pp. 107-108. Balogh Ferenc levele gr. Eszterházy Károlyhoz. 1763. máj. 12.

42 MNL OL EPL Domínium Pápa. P 1216 A pápai uradalom lajstromozott iratai. C. 51. N. 1. Prothocolum Papense Correspondentiarum a dato 30 Octobris 1759 usque 26 $6^{\text {ae }}$ Novembris 1766 inclusive. pp. 127-128. Balogh Ferenc levele gr. Eszterházy Károlyhoz. 1764. jan. 4.

43 MNL OL Helytartótanács Levéltára. Departamentum Urbariale C 59 Úrbéri tabellák. Veszprém, Zala, Győr vármegyék

44 Fülöp É. M.: A pápa-ugod-devecseri Esterházy-uradalom megszervezése i. m. 260-267.

45 MNL OL EPL Domínium Pápa. P 1216 A pápai uradalom lajstromozott iratai. C. 51. N. 1. Prothocolum Papense Correspondentiarum a dato 30 $0^{\text {ae }}$ Octobris 1759 usque 26 $6^{\text {ae }}$ Novembris 1766 inclusive. pp. 111-113. Balogh Ferenc levele gr. Eszterházy Károlyhoz. 1763. jún. 14. 
telepített falvak ún. örökös szerződéseit (perennalis contractus, ewiger Vertag) s a szűk határú irtásfalvak számára kidolgozottakat. ${ }^{46}$

$\mathrm{Az}$ új szerződések életbe léptetésére irányuló uradalmi törekvések előzményei között meg kell említenünk azt a folyamatot, amikor is az 1740-es évektől Balogh Ferenc új kontraktusok megkötésére törekedett az általa irányított uradalmak jobbágyfalvaival. Ekkortól ugyanis a „bővülő értékesítési lehetőségek előtérbe helyezték a szolgáltatások közt a termény- és munkajáradék visszaszorulásával, a pénzjáradékot” ${ }^{47}$ Az ekkor megszületett egyezségeket a robotszolgáltatás megváltása jellemezte. A tatai uradalomban a tisztán német jobbágyokkal telepített falvak fentebb említett ún. örökös szerződései, ${ }^{48}$ valamint az ezek mintájára végrehajtott átfogó, 1750. évi uradalmi regulatio már számos olyan elemet tartalmazott, mely később az úrbéri szabályozásban is megjelent: „A német falvak szolgáltatási rendje az uradalom számára olyan előnyöket jelentett, hogy ezek mintájára 1750-ben az egész uradalom területén egységesítette a jobbágyi szolgáltatások rendjét." ${ }^{39}$

Balogh régens Eszterházy Károlyhoz írt, ismert utolsó levele 1765 januárjában kelt. ${ }^{50} \mathrm{Az} 1764 / 65$. évi országgyülés fó tárgyalt témái közül az egyik az adóemelés ügye volt, ${ }^{51} \mathrm{~s}$ ez messzemenően összefüggött a jobbágyterhek szabályozásával, az úrbérrendezéssel. Ez utóbbi érdemi tárgyalását azonban a rendek elvetették..$^{52}$ A várható, jobbágyi szolgáltatásokat érintő szabályozásra reagálva Balogh Ferenc levelében az uradalmak haszonvételei között a kisebb királyi haszonvételek (regálék) általa mindig is vallott fontosságát hangsúlyozta a püspöknek, hiszen ezek független

46 Így aligha lehet kétséges, hogy ezek a mintegy mintául szolgáló szerződések, illetve Balogh elgondolásai tükröződtek a püspöki birtokon az 1763-tól indulóan megkötött, a bevételek növelését célozó, a szolgáltatások összetételét szabályozó új úrbéres szerződésekben. Lásd a Bán P.: Az egri püspöki uradalom i. m. 260.

47 Fülöp E. M.: A pápa-ugod-devecseri Esterházy-uradalom megszervezése i. m. 239.

48 Fatuska János: Gesztes a 18. és 19. században. In: Várgesztes. Szerk. Hartdégen Sándor - Rabazzi Stepancsics Gusztáv. Várgesztes 2008. 78-79.

49 Fatuska János: A tatai és gesztesi uradalom újranépesítése a török kiűzése után. In: Kecskéd település-története. A község újratelepítésének 200. évfordulója tiszteletére. Szerk. Fatuska János - Fülöp Éva Mária. Kecskéd 2007. 150.

50 Balogh Ferenc 1765 februárjában hunyt el Tatán. MNL OL X Tata, rk. halotti anyakönyvek. A 19/39 RK 603/17-20.

51 Ismeretes, hogy az országgyülésen a másik, az adóügyekhez szorosan tartozó, kiemelt fontossággal tárgyalt téma a nemesi felkelés (inszurrekció) szabályozása volt, amely a nemesi adómentesség kérdését is érintette.

52 „Az országgyủlés fó tárgya az adóemelést követően az úrbérrendezés lett. Az ország rendjei ahhoz ragaszkodtak, hogy az úrbéri ügyek ne közigazgatási, hanem bírói útra kerüljenek, és a nemesi kiváltságok (vélt és várt) sérelmei miatt igen merev álláspontot foglaltak el. Az alsótábla elutasította a királynő utolsó leiratát, a felsőtáblának a rendek által is elfogadott áthidaló javaslata viszont túl későn jött: a diétát bezárták, és az úrbéri viszony törvényi szabályozásának ügye elbukott." Szijártó M. István: A diéta. A magyar rendek és az országgyülés, 1708-1792. Keszthely 2010. 255. 
bevételt jelentettek az uradalmi alattvalóktól várható jövedelmek mellett: „Az mostani Diaeta ujjabb oktatást ád, és erőssit régi Principiumomban, hogy az földes úri regálék mindenek előtt tellyes szorgalmatossággal és igyekezettel administráltassanak. Ezekben Principaliter keresheti az földes úr maga hasznát, és innend a contribuens jobbágynak ereit is conserválhattya, és elő menetelihez módot találhat." ${ }^{33}$

1765-ben Veszprém vármegye, amelynek területén a pápa-ugod-devecseri jószág irányító központja és tartozékainak (a Zala, Vas és Győr vármegyei birtokrészek mellett) nagy része feküdt, ${ }^{54}$ elrendelte, hogy a szeptemberi vármegyegyulésig az urbáriummal nem rendelkező, contractust sem bíró helységeknek úriszéken urbáriumot adjanak, majd azokat a vármegyénél referálják. Eszterházy Károly egyelőre a halogatást választotta, igyekezett elodázni ennek megtételét. Várakozó álláspontja azonban, miután az új szabályozás bekövetkeztének elkerülhetetlenségéről megygyőződött, 1767 elejére gyökeresen megváltozott. Arra törekedett, hogy ő maga adjon urbáriumot uradalmi alattvalóinak, a várható egységes szabályozásnál talán az uradalom részére előnyösebb megállapodásokat kötve. ${ }^{55}$ Mária Terézia 1767 . évi úrbéri rendeletével azonban ez már végre nem hajtható próbálkozásnak bizonyult.

53 Ennek megfelelően, tavaszra építőanyagokat akart előkészíttetni, kocsma, vendégfogadó építéséhez. MNL OL EPL Domínium Pápa. P 1216 A pápai uradalom lajstromozott iratai. C. 51. N. 1. Prothocolum Papense Correspondentiarum a dato $30^{\text {ae }}$ Octobris 1759 usque $26^{\text {ae }}$ Novembris 1766 inclusive. pp. 165-166. Balogh Ferenc levele gr. Eszterházy Károlyhoz. Tata, 1765. jan. 5 .

54 MNL OL S 18 Kisebb családi fondokból kiemelt térképek; Gróf Esterházy Károly Múzeum, Pápa (a továbbiakban: EKM) Lt. sz. 64.149.1.

55 Fülöp É. M.: A pápa-ugod-devecseri Esterházy-uradalom megszervezése i. m. 262-263. 


\section{Agricultural Production on the Feudal Estates of Pápa-Ugod-Devecser of the Esterházys in the $18^{\text {th }}$ Century}

Count Károly Eszterházy (1725-1799), Bishop of Eger, acquired these domains as a patrimony in 1762 due to the landowning classification with his brothers among their inherited properties.

In the $18^{\text {th }}$ century the manorial lands of Pápa-Ugod-Devecser had strong connections with the Transdanubian estates of the younger Fraknó (Forchtenstein) line of the Esterházy family, regarding mainly the Tata-Gesztes estates. This period saw the Urbary Regulation in 1767, when the villein socage of serfs was regulated by the state.

The Bishop's economic activity, as well as his patronage of science and arts were significant. The Bishop entrusted Regent Ferenc Balogh of Galánta (1708-1765) at Tata with the management of these estates, and the family's property as well. So from 1762 onwards, Ferenc Balogh, who had great reputation in economy management of that time, also managed the family estates of Károly Eszterházy. After his death in 1765, the prefect (estate steward) at Pápa was running the estates.

Regent Balogh, as the appointed governor of domain of Pápa-Ugod-Devecser, managed the agricultural production based mainly on his experiences at the TataGesztes estates.

Among the agricultural products of these estates were primarily grain and timber. Because most of the domain was situated in the territory of Bakony mountain, they could increase their income by pig-breeding. Pasture leasing and wine sales were the leading sources of income. It was important that Regent Balogh reorganized the domain's forestry.

They enhanced the rate of market-oriented production. Their aim was to increase manorial production by increasing the number of farm-labourers and draft animals. They also cancelled the leasing of the so-called right of regalia (ius regaliae).

To increase the quantity of grain to sell, the domain demanded from their serfs to pay the ninth tenth of their income and the tithe (decima) in kind.

This period can be considered an interesting transition from the empirical to theory-based farming. The training of young people for an economic career under the supervision of the Regent in the different economic offices at the Tata domain employed the continuation of the old empirical method, and at the same time it was a forerunner of higher agricultural education for estate officers' training in Hungary at the end of the $18^{\text {th }}$ century. There were close connections between the estates officials' training for the family possessions of Károly Eszterházy and for the property of his episcopal benefice. 
Because of the expected state socage regulations, the Bishop and his estates' Regent made great efforts to sign new contracts (urbary, urbarium) with the serfs in favour of the domains.

\section{Hospodárenie esterházyovského panstva v 18. storočí (Pápa-Ugod-Devecser)}

Výhradné vlastníctvo panstva Pápa-Ugod-Devecser získal jágerský biskup gróf Karol Eszterházy po rodovej majetkovej del'be v roku 1762. Panstvo bolo v 18. storočí mnohonásobne prepojené s ostatnými zadunajskými panstvami fraknovskej línie Esterházyovcov, najmä panstvom Tata-Gesztes. V tomto období bol vydaný urbársky patent Márie Terézie (1767). Hospodárska činnost biskupa Eszterházyho nezaostávala za jeho aktivitami podporujúcimi umenie, či vytvárajúce podmienky rozvoja vedy, preto výskum tejto témy je takisto relevantný.

$\mathrm{V}$ začiatkoch svojho samostatného hospodárenia prenechal riadenie panstva na vel'aváženého prefekta/regenta panstva Tata-Gesztes, Františka Balogha, ktorý v jeho službách vykonal skutočne záslužnú prácu. Po Baloghovej smrti (1765) pokračovala správa panstva pod vedením prefekta so sídlom v Pápe. Tunajšie hospodárenie vynikalo najmä $\mathrm{v}$ tradičnom predaji dreva, vína a obilia. Okrem posilňovania alodiálneho hospodárstva sa snažili aj o prinavrátenie regálií a vlastnoručne sa ujali pivných domov, páleníc ako aj výčapov, ktoré prinášali čoraz väčší osoh. 